\title{
TROPICAL HYGIENE IN BRITISH, GERMAN, AND FRENCH COLONIES.*
}

\author{
BY SURGEON GLOAGUEN, M.D., \\ Of the French Navy.
}

WHILE cruising along the eastern coast of Africa, Dr. Gloaguen made a special study of the medical conditions of the various colonies. $\mathrm{He}$ was surprised to find that the British are behind the Germans in the matter of making and keeping their possessions healthy. The English fall back on their egotism and individual hygiene; the Germans on their inflexible militarism, and the French on their proverbial heedlessness.

The English conception of prophylaxis is very simple. It is based on two things : entire separation of the native and the European villages, and strict application of the principles of private hygiene. The English lead an active life, with athletics, etc., to keep mind and body in a healthy condition; they reside in comfortable cottages, but they make no effort to render the country healthier, and improve the sanitary conditions of the natives. There is no attempt at a general plan of campaign against tropical diseases. The native quarters are left in their filth, and fall an easy prey to diseases. Plague is installed in nearly all the British colonies on the Indian ocean, and with a few exceptions, no satisfactory measures have been taken even against malaria.

The Germans, on the other hand, have undertaken the task of exterminating disease among the natives and Europeans alike. The same sanitary measures are enforced in the native as in the European quarters. Hospitals are being organized at the main points, and the country is divided into districts, each in charge of an agent empowered to enforce the sanitary regulations. Medical stations are organized along the caravan routes, and the natives are examined, and registered, and given certificates. Laboratories are numerous. The streets in the native quarters have been made wide and airy, and are kept clean. The garbage is carted away daily, instead of being allowed to accumulate around the houses, as in the English and other colonies. Standing waters are drained or oiled. Quinine prophylaxis has been introduced by the Germans on an extensive scale at Dar-Es-Salaam. The native quarter is divided into 22 precincts, and they are visited by trained men and women, who obtain blood for bacteriological examination. In 1897 between 50 and 60 per cent of the Europeans had malaria. The antimalaria campaign was commenced in 1901, and in two years the number of cases of malaria among the Europeans had dropped to 10 per cent, with no mortality. Scarcely one in a thousand of the natives now harbours the malaria parasite, and the results are considered a brilliant success. Wherever he went in the French colonies he constantly heard the complaint: "If only this country belonged to England, it would have been made healthy long ago." The French are now trying to introduce some semblance of the German measures into their colonies, and with some success.

[Although the above may be regarded as not a fair representation of British methods, it is of interest as showing the opinion formed by an outside observer. The opinion of the French colonists does not appear to coincide with that of Dr. Gloaguen.-EZ.]

\footnotetext{
* Semaine Medicale, April 11th, 1906.
} 